\title{
Article
}

Assiut University web-site: www.aun.edu.eg

\section{THE INFLUENCE OF DEAD ANIMALS ON PUBLIC HEALTH AND THEIR DISPOSAL MANAGEMENT}

\author{
ZAHIR ABDULLATEEF JAMEEL BABACA
}

Department of Nursing, Bardarash Technical Institution, Duhok Polytechnic University, Duhok, Iraq

Received: 14 February 2017; Accepted: 2 March 2017

\begin{abstract}
This work entails personal realistic views that were recorded and collected throughout many years in IraqiKurdistan Region which are based on author's own experience. This paper discusses the safe disposal of animal carcasses through three recommended methods. I pleased that the views outlined in this paper are being implemented and promoted by a variety of organizations, including the World Health Organization, the human right Organization, the Municipal Authority, and the Veterinary Directorate. It is hoped that it will contribute in protecting the environment.
\end{abstract}

Key words: Dead Animals, Public Health, Disposal Management

\section{INTRODUCTION}

Dead animals are potentially dangerous because their death may be caused by infection with contagious diseases, like the bacteria that live on the flesh and wool of dead animals. These microbes can resist the harsh external environmental conditions for several years. These microbes may spread via air, which means increasing the scope of contamination. (Dead animals, 1995; Ristić et al., 2013).

The public and the media often react strongly to carcasses disposal because of the outbreak of diseases. This have save as a prompting to the local veterinary authorities to fulfill the disposal process according to scientific principles that are accepted in order to eliminate the pathogen, and to contain the public's reaction and the surrounding environment. (Sims et al., 1993).

The Recommended methods must comply with local and national laws, and should take into account the availability of resources. Furthermore, special strategies have to be developed for the disposal of carcasses (full or parts of bodies) before the occurrence of urgent cases. (Binford, 1998).

Corresponding author: Dr. ZAHIR ABDULLATEEF JAMEEL BABACA

E-mail address: zahir.abdullateef@dpu.edu.krd

Present address: Department of Nursing, Bardarash Technical Institution, Duhok Polytechnic University, Duhok, Iraq
Nowadays, when people travel through highways that link major cities, they would notice large numbers of carcasses on roadsides and in the middle of the road.

Throwing of dead animals in this way, not only has an impact on human health, but it is also considered as an uncivilized phenomenon and reflects the lack of appropriate follow-up from the authorities in charge. Moreover, these bodies distort the natural landscape (Ristić et al., 2008; Ristić et al., 2013).

On-Road carcasses usually belong to dogs and other wild animals like foxes and cats. These animals are hit by vehicles, especially during night hours when vision decreases. The bodies of these animals are often not removed by drivers from the highway.

Importance of Safe Disposal of Animal ByProducts

The necessity of solution for safe disposal of animal by-products by their utilization with processing into animal feed and bioenergents grows with the intensification of animal growing and the increasing of capacities of industrial slaughterhouses, creating new small slaughterhouses, building of plants for meat processing and increasing of the volume of international trade of commercial animal products. (Jean, 2012; Gwyther et al., 2011).

(Ristić et al., 2013) state that breeding stocks of animals exist the individuals, which in spite to the fact that they do not show any clinical signs of diseases, carry in themselves definite pathogens, 
which they during their life excrete into environment (feces, urine) and after their death or slaughtering such pathogens can be found in their carcasses or slaughterhouse wastes. Animals that died because of infective diseases, before their death bacteraemia, vitaemia (salmonellosis, red wind, swine plough and other carriers) were found. Some kinds of microorganisms even in state of agony of animal pervade all parts of the body ( $\mathrm{Cl}$. chonvorei, E. coli, $C l$. perfrigens), while others only after animal's death penetrate from the digestive system in all parts of the dyed animal ( $C l$. bifermentas, $C l$. bifoetidum), contributing to their degradation. Because of that, each died animal and inedible slaughterhouse byproduct should be regarded as the highest possible source of infection.

The same authors in their review on dangers of infections of humans that represent residues from cattle feeding production and prophylactic possibilities emphasizes that the use and disposal of animal wastes represents not only the technological, but, primarily, the hygienic question. That is the question of protection of spreading out of zoonoses and infections, adverse odors and dirt, as well as of endangering of surface - and underground waters with toxic waste waters. At that time, the author specifically emphasized on the role of dead animal corpses and the slaughterhouse wastes, particularly those from poultry production. Moreover, they indicated dangers that could represent household wastes as carriers of diseases of human beings. That confirms a number of references from professional literature, which state, for example that carriers of typhoid disease are able to survive in the sludge more than 40 days, and of pseudo-dysentery and of black boil (anthrax) even 80 days.

\section{Legislation and Regulatory Laws}

There should be a co-operation between the veterinary authority and other related governmental institutions as well as civil society organizations, and human rights organizations to identify legal and healthy procedures that aims at the removing dead animals to prevent any epidemic case. Within this framework, the following points must be regulated:

1. Promoting health awareness through advertising campaigns in media in collaboration with ministries of health and agriculture to urge people and make them aware about their commitment to these legislations.

2. Selecting the most appropriate location to throw these bodies in addition to the necessary equipment and facilities, after consulting local animal breeders and owners. This may be done through collaboration with relevant directories, including the local and central departments that are in charge of protecting public health and environment.
3. Those who are in charge of resource management should take into their account different issues such as staff, transportation, warehouses and equipment (e.g. mobile facilities and teams used for animals and tools cleansing), in addition to fuel and logistic support.

4. Providing rapid communication systems to update people and local authorities through observing any dead animal thrown on the highway.

5. Securing the health and safety of the staff. The process of removing the dead bodies should be done in a way that save workers' health from any potential risks of dead and decaying animals, especially from infectious diseases that may be transmitted to human being. A particular attention should be paid to training the workers and providing them with necessary protective clothing, gloves and face masks, respirators, glasses, immunization and antiviral medicines. Workers should be subjected to regular medical examination.

6. Environmental Issues: There are several ways to get rid of the carcasses and each method has a different effect on the surrounding environment. Burning generates smoke and odors, burial can generate gases while other leaks lead to air pollution, soil or surface water and groundwater.

7. Funding: adequate funding must be offered to handle the removal of dead animals. These funds have to be easily obtained when needed.

8. Acceptance and support of civil society to the procedure: The approval of civil society of the ways of removing the bodies of dead animals is also important. (ONTARIO REGULATION, 2006).

\section{Practical Issues}

1. Determination of carcass disposal site:

Disposal process requires sufficient quantities of sand to submerge the bodies. Other factors have to be considered such as the selection of soil and water drainage, the type of prevailing winds and easy ways to transfer, and provide information about the weather and staying away from urban areas and minimizing the effect of on the future of the site.

\section{Contractors:}

Contractors must be pinpointed, necessary man power and materials, including transportation vehicles should be secured. These vehicles have to be used only to get rid of dead animals. Appropriate roads have to be also secured to the desired goal. (Casper, 1993; Dead animals, 1995).

\section{Interviews:}


In order to determine which decision criteria are involved in carcass disposal practices in the KRG region, it should have conduct about 40 semistructured interviews with farmers located within a $50-\mathrm{km}$ radius from the core nesting sites. Open-end questions have specifically asked about: their past and current carcass disposal practices, their relationships with various stakeholders (i.e. sanitary authorities, private and government companies) and their perceptions of suitable method of carcass disposal.

\section{Recommended Methods for the Disposal of Dead Animals}

The risk to the public is negligible because they do not touch dead bodies. There is the potential risk of drinking water supplies contaminated by fecal material released from dead bodies.

Individuals handling human remains have a small risk through contact with blood and feces (bodies often leak feces after death) from the following: Hepatitis B and C, HIV, Tuberculosis, Diarrheal disease. (Morgan et al., 2006).

Removal methods must be selected based on the local conditions, the required energy, the speed of the results, and the conditions required to disable the pathogen.

1. Burning and incineration in private plants:

In such plants, the complete burning of dead animals or parts of them is performed and turned into ashes. This is done by the presence of other materials (e.g., cities wastes and hazardous waste of hospitals). This method disables pathogens, including spores (A guide to composting flood-related animal mortalities, 1999). Incineration facilities can be isolated permanently and they may have some advantages from the environmental viewpoint (Jean, 2012). Possible human health risks associated with on-farm burning (apart from physical burns and direct smoke inhalation) include the emission of dioxins from incomplete carcass combustion. Dioxins and furans are carcinogens and can negatively affect human reproduction, development and immune systems (Rier, 2008).

Such work should be supported by social studies to elucidate the fears and possible misconceptions associated with livestock burning so that effective communication of risk can occur.

\section{Outdoor cremation:}

It is an open system that is allowed to burn dead animals at the same site of facilities without transporting the remains of burning. This method, however, takes a long time and it does not verify the disabling of pathogens, and the particles rising from the burning process can spread. As the process takes place in front of the eyes of the audience, it could face rejection by the civil society. (Environmental guidelines for beef producers-11, 2000)

3. Burial of animal carcasses:

In this method, corpses are fully buried and covered with sand. The burial is a reliable method that can be implemented in the same site despite that it may not totally disable all pathogens. In some cases, dead bodies can be disposed by covering them with sand only. (Jean, 2012; Casper, 1993). Despite the seemingly low incidence of drinking water contamination with enteric pathogens arising due to burial of carcasses, some infectious material such as anthrax spores can reside within the soil after carcass decomposition (Nechitaylo et al., 2010).

\section{ACKNOWLEDGMENTS}

The authors express their sincere thanks to Mr. Nazar M. Tawfeeq, PhD in Translation, Duhok Polytechnic University, for comments that greatly improved the quality of English grammar and spelling of this manuscript.

\section{REFERENCES}

A Guide to composting flood-related animal mortalities. (1999): Raleigh, NC: North Carolina Department of Environmental and Natural Resources.

Binford, S.R. (1998): A Structural Comparison of Disposal of the Dead in the Mousterian and the Upper Paleolithic. Southwestern Journal of Anthropology. Vol. 24, No. 2, pp. 139-154.

Casper, J. (1993): The Maryland plan for disaster recovery: disposal of dead animals. J Am Vet Med Assoc. 203: 997-999.

Dead animals. In: Rules of Georgia Department of Agriculture. Eradication, control, and suppression of animal and poultry disease. (1995). Atlanta: Office of the Secretary of State.

Environmental guidelines for beef producers-11: dead animal disposal. Ministry of agriculture and food, province of British Columbia, Canada. Accessed Jun 29, 2000.

Gwyther, C.L.; Prysor Williams, A.; Golyshin, P.N.; Edwards-Jones, G. and Jones, D. (2011): The environmental and biosecurity characteristics of livestock carcass disposal methods: A review. Waste Management 31; 767-778.

Jean E. Sander; DVM, MAM, DACPV; Martin C. Warbington, DVM; Lee M.Myers, DVM, MPH, DACVPM. (2012): Selected methods of animal carcass disposal. JAVMA, Vol 220, No. 7, April 1. Vet Med Today: Special Report.

Morgan, O.; Binz, M.T. and Van Alphen, D. (2006): Management of Dead Bodies after Disasters: A Field Manual for First Responders. PAHO 
HQ Library Cataloguing -in- Publication. Washington D.C.

Nechitaylo, T.Y.; Timmis, K.N.; Byzov, B.A.; Kurakov, A.V.; Belogolova, E.; Jones, D.L.; Ferrer, M. and Golyshin, P.N. (2010): Fate of prions in soil: degradation of recombinant prion in aqueous extracts from soil and casts of two earthworm species. Soil Biol. Biochem. 42, 1168-1171.

ONTARIO REGULATION 302/06. DEAD ANIMAL DISPOSAL ACT. (2006): The Ontario

Gazette: Published on e-Laws, (Amending Reg. 263 of R.R.O. 1990).

Rier, S.E. (2008): Environmental immune disruption: a comorbidity factor for reproduction? Fertil. Steril. 89, e103-e108.
Ristić, M.; Okanović, Đ. and Radusin, T. (2008): Contemporary approach to annimal byproducts disposal problems. Food Processing, Quality and Safety 35, 2, 81-92.

Ristić, M.; SakačMarijana, Filipović, S. (2013): Animalni otpaci i njihova sanacija uSrbiji, Međunarodna eko-konferencija: Zaštita životne sredine gradova i prigradskih naselja, 397-401, Novi Sad.

Sims, J.T.; Murphy, D.W. and Handwerker, T.S. (1993): Implications for Dead Poultry Disposal and Manure Management. Journal of Sustainable Agriculture, Volume 2, Issue 4. 